\section{THE TRANSCONTINENTAL EXCURSION OF THE AMERICAN GEOGRAPHICAL SOCIETY}

ON the evening of August 21 there was gathered at dinner at the Harvard University Club in New York City a somewhat unusual company. Of those present forty-three were European geographers, representing fourteen different countries. There were also present about a dozen Americans, and all together were making the beginnings of acquaintance and friendship which in many cases will be lifelong. The occasion of the excursion was the completion on upper Broadway of the American Geographical Society's splendid new building. Though unannounced, it is well understood that the two months of journeying which followed was made possible through the munificence of the president of the society. The party had been organized, and the excursion was directed by Professor W. M. Davis, of Harvard University. The start was made from the Grand Central Station at 8:30 on the following morning. The special train was made up of two Pullman cars, two Pullman observation cars, a diner and a baggage car. There was also usually attached to the train a private car accompanied by some official of the several railways along which the route was taken. These officials were usually in charge of the land holdings and of the industrial operations which are now so largely promoted by our great railway systems in the west and the south. They are accomplished men and gave to the party many valuable lectures and conversations throwing light upon the development of their respective regions. A very complete outfit of maps had been provided, and the map expert of the society hung in the observation cars large and small scale maps appropriate to the regions through which we were passing daily. There were also considerable libraries, made up of the books and papers of the American members of the party and of the reports of the Geological and Geographical Surveys of the United States, and of the various commonwealths.

It would not be easy to define in a single sentence the object and work of the excursion.
The main aim, of course, was for every man to get as much first-hand knowledge about the United States as possible. This was attained in many ways. There were considerable observations from the car windows so long as daylight prevailed, and there were many stops, sometimes two or three in a day, for special features of the physical geography. Thus, in Fishkill, a little more than an hour out of New York, the party alighted from the train and ascended by the cable car to the summit of the highlands, where one of the American members interpreted the topography of the mountains, and the industrial and commercial interests of the Hudson River lowlands as they spread out northward towards Albany. At Little Falls a brief stop was made. The Dolgeville railway was ascended to the top of the cliffs and the topography and history of the Mohawk Valley were briefly described, and a representative of the state engineer's office added an account of the Barge Canal. At Syracuse the party was taken by automobiles southward from the city to see on the hills the abandoned river channels and fossil Niagaras of the closing stages of the glacial time. On the banks of the Mississippi River in the early morning the train stopped for an hour while the party scrambled to the top of the bluffs to look out over the delta of the Chippewa, and the ponded waters of Lake Pepin. The topography around San Francisco was seen by a long walk through the rift valley, marked by the earthquake movements of 1906, and also by the railway ascent to the summit of Mount Tamalpais, whose magnificent panorama includes the city, the Golden Gate, San Francisco Bay and broad stretches of the Valley of California. At Loch Ivanhoe, in Colorado, the train stopped at the western entrance of the tunnel, and the party walked over the Hagerman Pass of the Continental Divide, rejoining the train at the other end of the tunnel. At Asheville, one of the local summits of the Appalachians was reached by automobile and here lunch was taken looking out upon the wilderness of peaks and endless forests that characterize the mountains of North Carolina. 
In addition to daily studies of the physical features from the train and by special excursions, a great deal of attention was given to the phases of economic and industrial development, for it is recognized by all true geographers, and it is especially emphasized by the geographers of Europe, that the science does not come to its full fruition until it has taken in, not only the lands, but the interests and relations of those who live upon them.' Every one knows that a wide field for such study is open to one who crosses our continent.

From Buffalo the party visited the Lackawanna steel plant and for an hour or more were transported up and down among the various buildings and furnaces upon flat cars provided by the company. At Niagara one afternoon was devoted to the power house and the various industries, and the whole of the following day given to the falls and the gorge, with many stops and brief lectures from experts by the way. In Chicago the party inspected in squads, according to their choice, the Stock Yards, the business methods of the Sears, Roebuck Company and the map-making plant of the Rand-McNally Company. A day was spent in the great open air iron pits of Hibbing, Minnesota, where again the party was transported by many miles of zig-zagging in a train of open cars to all levels of this greatest of iron mines. A characteristic stop of forty minutes was made in sight of one of the "bonanza" farms of North Dakota, where various phases of North Dakota agriculture were explained from the observation end by experts of the state agricultural college, the audience being assembled about the rear of the train. The Europeans were vastly interested in many phases of western agriculture, familiar to them by reading, but now seen for the first time. They and the Americans as well wondered at the extent to which dry farming has encroached upon the range country in North Dakota, Montana, Washington and other parts of the arid west. A notable example of such successful dry farming was seen in central Washington. The party alighted at a little station called Almira, and were met by twenty-five or thirty automobiles gathered from everywhere by the industry of a railway official, the main object being to see the Grand Coulee, some twenty-five or thirty miles of dry cañon once occupied by the Columbia River. On the way to this, however, a dozen miles or more of rolling country were passed, covered with splendid wheat fields, and the harvest was in progress by means of the combined reaping and threshing machines, drawn by motors or by teams of twenty horses. These crops were growing without irrigation in a region of perhaps twelve or fourteen inches of rainfall. In the Grand Coulee the party were entertained at an outdoor lunch on the ranch of a graduate of the University of Michigan, and the party learned then, as they learned many times in the west, that the graduates of our greatest universities are likely to be found wielding hard hands and wearing a pair of overalls. The after-dinner feature of this day was a good sample of broncho "busting," by the trained cowboys of the ranch. That particular day was finished by a visit to an irrigated fruit farm, where all the ladies of the region had apparently gathered, and the foreigners got a new treat in the shape of a hundred-foot table of sliced watermelon. At Tacoma the tallest member of the party, a Chicago professor, tried in vain to measure with up-stretched arm the diameter of a log which had been pulled up out of the pond, and was put to the saw under our eyes.

A few links in the excursion were made by trips over the water. At Toledo the party was entertained on the upper floor of a skyscraper, then taken across the foot of Lake Erie and up the Detroit River by boat. The blue waters of Puget Sound and the environing slopes of virgin forests and noble cities were likewise seen from the decks of a steamer. On the Mississippi River the party spent a happy day sailing from Memphis one hundred miles down the stream, watching the sand bars, snag boats, the means taken to protect the banks, the bordering forests, and it must be said-the lone steamer or two on waters that might carry the commerce of an empire. An old-fashioned landing was made 
in the twilight, head on to the shore, but it was not exactly old-fashioned to clamber up thirty feet of sand and find at the top a brilliantly lighted train of palace cars with dinner served.

There was much of a social and educational sort. Perfection of arrangement was shown almost every day, when promptly on the scheduled moment the train pulled into the station and with equal promptness a local committee stood upon the platform, and motor cars or electric cars awaiting the party stood in the street. There was the opportunity for acquaintance with the best types of American, which was by no means small, and the American members of the party in response to oftrepeated questions as to the state of the political weather, found the same muddled and unpredictable conditions with which they had become familiar east of the Mississippi River. One of the early stops was at Ithaca, where Mrs. R. S. Tarr, bravely fulfilling the desire of her lamented husband, who was to have been a member of the excursion, opened her home for a reception. Here the party met such members of the Cornell faculty as were at home during the summer, and gained some acquaintance with one of our universities, as they did also in Chicago, in Madison and other places. Many representative people were met at dinners held in Chicago, Duluth, Portland, Salt Lake City, Denver, Chattanooga and many other places. At the dinner in St. Paul the governor of Minnesota evinced his good wit by saying that he had never expected to see so many people who knew so much about the earth and owned so little of it, while Archbishop Ireland on the same occasion made a speech which, if a little long, was every word interesting and inspiring. It was not a little interesting to the French professors who sat at his side that he was quite their equal in the finished use of their native tongue. It is hardly to be believed that one hundred representative business men of any eastern town would come out by train at six o'clock in the morning a distance of fifty miles to meet a delegation of scholars, but this was done by the men of Fargo, in North
Dakota, and the skidding of the automobiles in the wet gumbo outside of Fargo gave one a lasting remembrance of the quality of the black prairie soil. One of the pleasant memories of the Pacific coast is the hours of inspection and entertainment on the campus of the new University of Washington in a glorious suburb of Seattle. Indeed if any European came to the coast cities expecting to find things a little crude, he was obliged to alter his conceptions, for he saw paved streets, splendid buildings and innumerable beautiful bungalow homes, embowered in blossoms and greenery that never fail during the twelve months. The friendliest of social times was had in the Muir Woods, a splendid reservation of redwoods near the Golden Gate, on the day when Mr. John Muir, Mr. Luther Burbank and Mr. Fred G. Plummer were members of the party. At the University of Utah the entire party sat on the platform at the chapel service attended by a thousand boys and girls and brief addresses were made by one German, one Swiss and one American professor. Santa $\mathrm{Fe}$ brought the party into an old Indian and Spanish realm, and after a morning with prehistoric remains, the old adobe church of San Miguel was visited, and the ladies and gentlemen of Santa $\mathrm{Fe}$ gave a reception in the museum, an old Spanish building, once the governor's palace, now used for purposes of archeology. It was not all archeology, however, for the refreshments were good, the attire might have been seen in Chicago or Philadelphia, and the reception was preceded by Indian war dances, with all the accompaniments of hideous sounds, feathers and barbaric display to which the civilized Indian is still able to return. On the home journey there was a Conference on Geographical Education held under the presiding of President Alderman at the University of Virginia. Here five of the foreign and two of the American teachers of geography gave addresses on the teaching of the subject in European and American universities, which will be published and circulated by the University of Virginia. In Washington there 
were a number of interesting entertainments consisting of dinners and receptions by the Carnegie Institution, the officers of the Congressional Library, the Cosmos Club and other institutions.

It will not be forgotten that men of the diligent type of the German and other European professors must have made volumes of various notes, and the crop of papers and books on America that may be expected in the coming years on the other side of the ocean may well be surprising. Records by photography were not the least. One of the strenuous Frenchmen took at least one thousand pictures, and it was ascertained by one of the Swiss members who had something of a genius for statistics and inquiry, that about twelve thousand photographs were made by the party as a whole.

One who had two months' experience of the excursion must almost say that the home life on the train was larger and more valuable than anything else. It surprised all to find that vehicles on wheels could become so thoroughly homelike, and it was the ordinary experience for members of the party returning even from the best of hotels to say: "We are glad to get back to the train."

The permanent American members of the party were about a dozen in number and represented Harvard, Yale and Columbia Universities, the University of Cincinnati, the State Normal College of Michigan, the Universities of Wisconsin and Chicago, Colgate University and the American Geographical Society. Many temporary members were with the party for one, two or three days at a time, in regions where they could serve as guides and helpers by reason of their own studies. A daily bulletin was issued on the train giving each day a full outline of the itinerary and work of the following day. There were endless conversations in the sleeping cars, on the observation platforms, in the observation parlors, in the dining cars, on platform steps, and everywhere. There were lectures in the train and off the train, indoors and out of doors, and as the party melted down together toward the end there were entertainments, improvised Indian dances, by a young Swiss professor, occasional mock scientific papers, taking off the foibles of the party, cartoons from the skillful hands of a number of the foreigners-in brief those bits of fun which enliven weariness and make work effective. It is a tribute to the perfection of American travel that in two months, with an average party of sixty-five persons, but one meal was served on the train, outside of the dining car.

Nothing has been said in this story of the great places. Of course they were visitedthe Yellowstone (six days), Crater Lake (three days), the Wasatch and Lake Bonneville, Great Salt Lake, and the irrigated fields and orchards of the valley, the Grand Cañon (the masterpiece of nature in North America), and not least, Phœnix and Roosevelt, where the Salt River Valley, the driest and hottest region of Arizona, is being turned into one of the gardens of the continent. Best of all was the acquaintance which developed and the friendships which were cemented. An eminent foreign professor in a fraternal gathering held in one of the cars before the train broke up said that he counted the excursion the culmination of his life, and he paid tribute to the universal hospitality that they had found, both among the home members of the party and the citizens of many communities, and he said that best of all, the men of Europe had come to know the American gentleman. Not only friendship must result, but broad and just views of America by a group of foreigners supremely qualified to understand. The excursion was a kind of geographical congress on wheels, and it was a means of international comity.

The final days in New York and the closing dinner at the Waldorf Astoria made a fitting end of the two months spent together. A memorial volume will be published which will include a history of the excursion by the author of this sketch, and a considerable number of geographical essays by European members of the party.

Albert Perry Brigham 